\title{
BALANCING THE INTERESTS OF TAXPAYERS AND TAX AUTHORITIES AS THE METHOD OF MINIMIZING TAX DISPUTES
}

\author{
Iryna Vasylieva ${ }^{1}$
}

\begin{abstract}
The author notes in the article that an increase in the number of tax disputes is influenced by many factors, including the constantly changing tax laws of Ukraine, low legal culture of taxpayers, the lack of professional training of representatives of tax authorities involved in tax audits, as the tax authority must correctly assess the circumstances, available facts and correctly apply to the facts of the current legal provisions, while preventing the abuse of power in making the relevant decision, which must be based on the public interest. A qualitative legislative regulation of the indisputable procedure for the collection of financial penalties will occur when financial penalties will be charged incontestably only in the absence of reasonable objections of the taxpayer, filed within the prescribed legal deadlines, that is, in the absence of a tax dispute. Finding a reasonable balance between the rights of taxpayers and the powers of the tax authorities should come to the fore when making changes to the tax legislation. The basis for achieving a balance between the interests of taxpayers and tax authorities can be served by proper explanatory and informational work. The state should develop a set of special measures to adapt taxpayers and employees of the tax authorities themselves to the action of the new tax legislation, regarding the corresponding change in their mentality, improvement of business cooperation and mutual understanding between them, increasing their responsibility for the performance of their tax obligations to the state and the realization of the rights provided by law. The institution of preliminary conclusions of tax authorities is proposed, which will simplify the assessment of tax losses by taxpayers in the planning of economic activities. The taxpayer submits an inquiry about the tax consequences of planned transactions and transactions with future counterparties for their riskiness. The tax authority then prepares and gives an opinion within two weeks.
\end{abstract}

Key words: tax dispute, balance of interests, taxpayer, tax authority, tax law, preliminary finding, public and private interests.

JEL Classification: H20, K34

\section{Introduction}

Payment of taxes is seen as an appropriate payment for the benefits and conditions created by society and used by the taxpayer to obtain property benefits or to provide a variety of vital needs. This is only possible if there is a fair balance between the interests of the taxpayer and the state, which is achieved by having clear and transparent "game rules" and paying great attention to protecting the rights of the taxpayer as a weak party in tax legal relations.

The principle of a fair balance between the interests of the taxpayer and the state has not received formal written enshrinement in the normative legal acts of Ukraine, but is considered to be effective because it is an extension of the component of the rule of law the principle of proportionality. The European Court of Human Rights has repeatedly pointed out in its

Corresponding author:

${ }^{1}$ Administrative Cassation Court within the Supreme Court, Ukraine.

E-mail: irina05072015@gmail.com decisions that the requirement of a fair balance between the general interest and the fundamental rights of the individual is inherent in all the articles of the Convention for the Protection of Human Rights and Fundamental Freedoms. In addition, the ECHR notes that the balance will not be met if individuals bear an excessive burden. In considering disputes, the ECHR always makes an assessment of the balance between public and private interest, with the main such assessment being the real balance of interests of the authorities with respect to enterprises, institutions, organizations and individuals.

The principle of fair balance in the relationship between taxpayers and the state, despite the lack of enshrined in the legal acts, is no longer something unusual for law enforcement practice, although it remains an uncommon argument for arguing the legal position of taxpayers. 
In recent years, there has been an increasing trend in the number of tax disputes in Ukraine. In previous years, given the number of cases considered by the Administrative Cassation Court within the Supreme Court, it is possible to see how the dynamics of resolving tax disputes in court has changed.

It should be noted that the increase in the number of tax disputes occurs against the background of an increase in the total number of appeals of individuals to administrative courts and an increase in the number of public-law disputes in general. The increase in the number of tax disputes is affected by many factors, including the constantly changing tax laws of Ukraine, the low legal culture of taxpayers, the lack of professional training of representatives of tax authorities involved in carrying out tax audits, as the tax authority must correctly assess the circumstances, the available facts and correctly apply to the facts of the current legal provisions, not allowing the abuse of power in making the decision, which must be based on the public interest.

By balancing private and public interests in the tax sphere, the presumption of legitimacy of the taxpayer's decision will reduce the number of court cases in which the parties are the taxpayer and the supervisory authority.

\section{Analysis of recent research and publications}

The issue of tax dispute resolution is a topical and studied issue in the domestic literature, in particular by such scholars as O. M. Bondarenko, O. O. Dmytryk, V. O. Kurylo, M. P. Kucheriavenko, K. V. Minaieva, A. O. Monaienko, Ye. A. Usenko.

In a market economy, taxes as a component of the system of public finance are one of the most effective and almost the only way to influence economic processes. At the same time, economic and social goals are pursued (for example, duties on imported cars, as a rule, are introduced to support domestic producers, and the reduction of income tax on bank deposits should attract funds of citizens to commercial banks).

Apart from taxes, the state has essentially no other methods of raising revenue for the state budget. The state can also use government loans to cover expenses, but they must be repaid and interest must be paid, which also requires additional revenues. Under special circumstances, the authorities resort to putting money into circulation, but this is associated with the country's dire economic consequences - inflation. As a result, taxes remain the main income of the country.

In market relations the dominant role in ensuring the balance of socio-economic development of the state belongs to fiscal instruments. The balance of the state economy is an integral concept, which includes such components as consistency of interests of different categories of participants of economic relations, optimal proportions between the sizes of all parts of the economic system, a reasonable ratio of its qualitative characteristics, the consistency of the pace of development of individual subsystems. The topic of violations of the balance of the tax system remains insufficiently developed. Of course, there is a need in science to study the processes, phenomena and problems that violate the balance of the tax system of the state and thereby create a threat to the economic security of the country.

The imbalance of the tax system creates unequal tax burdens and, as a result, leads to an increase in the shadow sector of the economy, tax evasion, and a decrease in tax revenues. This increases the real and potential threats to the economic security of the state.

Causes and conditions resulting in the imbalance of the tax system not only make it difficult to provide budget revenues in the planned volumes, but also make it impossible to fulfill the strategic objectives of the state as a whole. Such reasons include: uneven distribution of the tax burden; complexity and inefficiency of the tax administration system, which leads to tax disputes.

A notable problem of the domestic tax system remains the instability and ambiguity of tax legislation. A clearer and more comprehensible formulation of legal provisions in the tax legislation would contribute to the "correct application of law," which would comply with the practice of the European Court of Human Rights (paragraph 54 of the judgment of the ECHR of November 2, 2004 in the case "Tregubenko v. Ukraine").

The increase in the number of cases in the sphere of tax legal relations is also caused primarily by the growth of cases related to the incorrect application of tax legislation.

In Ukraine, most tax disputes are initiated by the tax authorities themselves, in particular - these are disputes on the collection of obligatory payments and the application of financial penalties for violation of $\operatorname{tax}$ legislation.

At the same time, the ratio of disputes initiated by the tax authorities and taxpayers should give rise to the view that taxpayers are not active in protecting their rights and interests violated by the tax authorities. Thus, taxpayers have recently been trying not to bring their tax disputes to court due to the fact that it will lead to a longer time of their resolution, the payment of court fees, as well as the cost of legal aid.

\section{Ways to reduce the number of tax disputes}

Ways to reduce the number of tax disputes can be different. But first of all, these should be measures aimed at improving the current tax legislation by making qualitative and clearer changes to it, which would further contribute to the correct application of tax legislation. In the decision of January 14, 2011 in the 
case "Shchokin v. Ukraine," the ECHR noted that the national legislation of the State must be clear and coherent, as well as the requirement of the national authorities to apply an approach that would be most favorable to the applicant.

In addition to the need to clarify the principles of taxation, directly related to the formation of the psychology of conscientious taxpayers, and thus improve tax culture in society, when making changes to the Tax Code of Ukraine it is necessary to clarify the tax legislation in matters of more complete definition of the rights and obligations of the main subjects of tax legal relations - taxpayers and tax authorities.

Improvement of the legal status of the taxpayer and the powers of the tax authorities may have an impact on reducing the number of tax disputes.

According to article 23 of the Constitution of Ukraine, every person shall have the right to free development of his personality, provided that the rights and freedoms of other persons are not thus violated, and shall have duties to society, in which free and comprehensive development of his personality shall be guaranteed. Therefore, the Tax Code of Ukraine, on the one hand, establishes the limits of permitted behavior of taxpayers and certain guarantees of protection of their rights in relations related to the execution of the constitutional duty to pay taxes, on the other hand, establishes the limits of powers for the tax authority. The problem of establishing the balance of interests and opportunities of the main participants of tax legal relations, although it was the focus of attention during the development of the Tax Code of Ukraine, but not solved sufficiently.

The ECtHR is guided by the principle of a fair balance between the private and public interest, as there is always a wide margin of appreciation in the tax sphere in states. Deprivation of property, interference in the use of property, control over the use of property by the State must be justified by the relevant purpose pursued by the State in implementing control measures, as well as be consistent with the principle of a fair balance between private and public interests (ECHR judgment in Sporrong and Lonnroth v. Sweden, 1982).

The State has wide discretion both in choosing the method of taking control measures and in determining whether the effects of such measures are justified in view of the public interest in achieving the purpose of the law (ECHR decisions in Zvolský and Zvolská v. the Czech Republic, 2002).

The task of the Tax Code of Ukraine No. 2755-VI of December 2, 2010, is to ensure a reasonable balance between the interests and rights of taxpayers and the powers of the tax authorities. This, in turn, is the main reason for the effective and fair functioning of the fiscal system of the state. Moreover, fairness of tax legislation should play a decisive role in overcoming the negative attitude of taxpayers to the tax system.
As noted by A. P. Balakina, the area of tax relations is an area of close collision and interaction of private and public subjects. In a democratic social state, public subjects in the establishment of regulatory requirements addressed to private subjects, must take into account and respect their interests (Balakina, 2005).

In tax law, the relationship between the subjects of private and public law is based on the principles of inequality of participants of tax legal relations, their subordinate nature. At the same time it is necessary to contrast the subjects of private and public law. It is more constructive to find an optimal combination of their interests, development of effective ways of their interaction.

The state through the mechanism of taxation provides its fiscal interests on formation of funds in the centralized monetary fund to implement its own tasks and functions. Establishment of tax burden contributes to the realization of the common good, the implementation of public functions by the state, as it realizes the public interest of all members of society.

Thus, to date, one of the main objectives to reduce the number of tax disputes should be the development of conceptual foundations for reforming tax relations in order to achieve the maximum balance of interests of the parties involved in the process of taxation.

Finding a reasonable balance between the rights of taxpayers and the powers of the tax authorities means the need to limit the coercive measures applied to the taxpayer to the extent necessary to ensure that the state performs its functions. This principle should be fundamental in the further development of the provisions of the Tax Code of Ukraine.

\section{Measures to ensure the fulfillment of the tax obligation}

In this regard, one of the main issues that should be emphasized in terms of the power of the tax authorities is the possibility of using an indisputable order to address only some issues of tax administration (in particular, on the application of measures to ensure compliance with tax obligations). This has become especially relevant recently in connection with the application of administrative seizure of funds and property of taxpayers.

Thus, according to Part 94.1 of Article 94 of the Tax Code of Ukraine the administrative seizure of property of the taxpayer is an exceptional way to ensure the execution of the taxpayer of his obligations defined by law (Tax Code of Ukraine from December 2, 2010 № 2755-VI).

Seizure of property may be applied if one of the following circumstances is found: the taxpayer violates the rules of alienation of property that is in tax pledge; 
an individual with a tax debt goes abroad; the taxpayer refuses to conduct a documentary or actual inspection when there are legitimate grounds for it or to allow officials of the supervisory authority; there are no permits (licenses) to carry out business activities, as well as in the absence of registers of settlement transactions and/or software registers of settlement transactions registered in the manner prescribed by law, except in cases specified by law; there is no registration of the person as a taxpayer with the controlling authority, if such registration is mandatory under this Code, or when the taxpayer, who received a tax notice or has a tax debt, performs actions to transfer property outside of Ukraine, conceal it or transfer it to other persons; the taxpayer refuses to conduct an inspection of the state of storage of property in tax pledge; the taxpayer does not allow the tax manager to draw up an act of description of the property transferred to tax pledge (Tax Code of Ukraine from December 2, 2010 № 2755-VI).

The Tax Code of Ukraine in article 20 establishes the rights of supervising bodies. Below are only part of them (Tax Code of Ukraine from December 2, 2010 № 2755-VI):

- to invite taxpayers, levies, payments or their representatives to check the accuracy of accrual and timely payment of taxes, charges, payments, compliance with legislation on other issues, including legislation in the field of prevention and counteraction to legalization (laundering) of proceeds of crime or terrorist financing, control over compliance with which is assigned to the regulatory authorities;

- analyze the financial condition of a taxpayer who has a tax debt and the condition of securing such debt with a tax lien;

- receive free of charge information, documents and materials on taxpayers from state bodies, local authorities, enterprises, institutions and organizations of all forms of ownership and their officials, including bodies that maintain relevant state registers (cadastres), and in cases specified in this Code with respect to heads of legal entities or permanent representations of non-resident debtors;

- request and examine during inspections primary documents used in accounting, registers, financial, statistical and other reports related to the calculation and payment of taxes, fees, payments, compliance with the requirements of the legislation, control over compliance with which is entrusted to the supervisory authorities;

- receive from taxpayers, single contribution payers and provide, to the extent provided by law, documents in electronic form;

- when conducting inspections of taxpayers individuals, as well as officials of taxpayers - legal entities and single contribution payers to check identity documents, as well as documents confirming the position of officials and/or persons actually carrying out settlement operations;

- require during audits of taxpayers under audit, to conduct an inventory of fixed assets, inventories, funds, withdrawal of balances of inventories, cash, using the information and documents from such an inventory on the results of such audits or during subsequent tax control measures;

- apply to court, including filing lawsuits against enterprises, institutions, organizations and individuals regarding the invalidation of disputed transactions and the application of certain legislative measures related to the invalidation of transactions, as well as the recovery of funds received for null contracts to the state.

The problem of minimization of tax disputes, primarily resolved by administrative procedure, the state is trying to solve through the adoption of the Law of Ukraine "On Administrative Procedure", thereby regulating the process of making the appropriate decision and procedural features of the application of a person to the subject of authority. However, the adoption of tax notices-decisions is regulated by the Tax Code of Ukraine, which is a special act to apply compared to the Law "On Administrative Procedure".

Some authors justify the provision that the resolution of tax disputes should not be carried out otherwise than through the courts. For example, I. V. Panova believes that the tax authorities should violate administrative proceedings and within the prescribed statutory time limits to submit to the judicial authorities a statement of claim for the application of penalties for violation of tax legislation (Panova, 2000).

S. A. Herasymenko believes that the indisputable procedure for the recovery of arrears is a consequence of the fact that the legislator proceeds from the presumption of bad faith and bad faith of taxpayers. In this case, on the contrary, the legislator idealizes the level of competence, integrity and impartiality of tax officials (Herasymenko, 1994).

There is also a discussion that measures to enforce taxpayers' tax obligations violate their rights and interests, limit their economic activities in terms of the use of funds for payment for goods and semi goods, as well as property that can be alienated in the process of activity, resulting in the eventual narrowing of rights of taxpayers.

However, according to the decision of the Constitutional Court of Ukraine of June 12, 2012 № 13-rp/2012 on the case on the constitutional representation of 53 people's deputies of Ukraine on compliance with the Constitution of Ukraine (constitutionality) of certain provisions of the Tax Code of Ukraine full administrative seizure of property of the taxpayer is a ban on the realization of rights of disposal or use of his property; in this case, the risk associated with the loss of functional or consumer 
qualities of such property is borne by the body that made the decision on such a ban (Decisions of the Constitutional Court of Ukraine of June 12, 2012).

According to paragraph 94.10 of Article 94 of the Tax Code of Ukraine, the seizure of property may be imposed by decision of the head of the State Tax Service (his deputy), the validity of which should be verified by the court within 96 hours.

Section 119.2 of Article 119 of the Code provides for the imposition of fines for failure to submit, submitting within the prescribed period, not in full, with incorrect information or errors in the tax returns on the amount of income accrued (paid) in favor of the taxpayer, the amount of tax withheld from them.

The Constitutional Court of Ukraine in its decision recognized the provisions of the Tax Code of Ukraine as compliant with the Constitution of Ukraine (being constitutional), namely (Decisions of the Constitutional Court of Ukraine of June 12, 2012):

- Subparagraph 94.2.2 of Paragraph 94.2 of Article 94, according to which administrative seizure of property of the taxpayer is applicable if it turns out that an individual with tax debt is going abroad;

- Subparagraph 94.2.5 of Paragraph 94.2 of Article 94, according to which an administrative seizure of property of the taxpayer may be applied if it is found that the registration of the person as a taxpayer in the body of the State Tax Service, if such registration is mandatory under this Code, or when the taxpayer, who received the tax notice or having tax debt, committed actions to transfer property outside of Ukraine, its concealment or transfer to other persons.

Given the above views, it should be noted that it is certainly not advisable to transfer to the judiciary the full control over the activities of the tax authorities.

\section{Ways to harmonize relations between taxpayers and tax authorities}

There is also a discussion in the science of tax law about the need to amend the Tax Code of Ukraine and the introduction of a mechanism of indisputable collection of financial penalties for certain types of violations of tax laws, but, in the author's opinion, such a procedure should be clearly regulated by tax law to avoid contradictory situations in practice. If such actions the tax authorities will be entitled to perform, it will violate the sphere of interests of the taxpayer. Therefore, under such conditions, the ways to protect the taxpayer's rights in the collection of taxes and financial penalties from him in an incontestable manner are of particular importance.

Taxpayers should be explicitly given the opportunity to appeal the tax notification-decision of the supervisory authority to recover financial penalties from him in the case of his disagreement with such a notification-decision, and the time frame must be sufficient for the implementation of this right. According to Part 2 of Article 124 of the Constitution of Ukraine, the jurisdiction of the courts extends to any legal dispute and to any criminal charge. In cases stipulated by law, the courts also hear other cases.

In other words, the indisputable procedure for the collection of financial penalties will violate the taxpayer's right to appeal against the relevant decision of the tax authority.

According to the author, a qualitative legislative regulation of the indisputable procedure for the collection of financial penalties will take place, provided that financial penalties will be charged incontestably only in the absence of reasonable objections of the taxpayer, filed within the prescribed legal period, that is, in the absence of a tax dispute.

In this case, restrictions on the right to judicial protection will meet the requirements of necessity and sufficiency, valid for the given period and ensuring a balance between public and private interests. At the same time, as long as the tax authorities are not interested in settling tax disputes out of court - by entering into conciliation agreements, the situation will not change, but there will only be changes in the structure of tax disputes resolved in court - instead of claims of tax authorities to recover financial penalties, a large number of taxpayer lawsuits on the appeal of such decisions will appear.

Thus, the search for a reasonable balance between the rights of taxpayers and the powers of the tax authorities should come to the fore when making changes to tax legislation. It is about the need to harmonize tax relations, which is understood as the maximum convergence of divergent and in some cases directly opposite interests of all parties to these relations involved in the taxation process (the state represented by the tax authorities, on the one hand, and taxpayers, on the other hand). Harmonization of tax relations is one of the main conditions for successful implementation of any tax reform.

The state, accordingly, should develop a set of special measures to adapt taxpayers and employees of the tax authorities themselves to the action of the new tax legislation, concerning an appropriate change in their mentality, improvement of business cooperation and mutual understanding between them, increasing their responsibility for the performance of their tax obligations to the state and the realization of the rights provided by law.

The taxpayer must not see tax officials as adversaries, but as partners in the tax process. That is why any tax service must be strictly guided and guided not only to conduct periodic information campaigns of explanatory nature, dedicated mainly to the latest changes in tax law, reports and tax returns, and therefore having a purely situational nature, but to create a comprehensive, flexible and mobile system of quality 
information service, providing the necessary methodological and advisory assistance to taxpayers.

\section{Foreign experience of obtaining information from tax authorities}

Active use by the taxpayer of his rights to obtain information from the tax authorities, for example, in connection with the taxation of income from agreements to be concluded in the future will allow to solve the problem before it arises, which will eliminate the need to resolve the dispute with the tax authority. In this case, it is advisable to use the experience of developed countries in this area.

Thus, in foreign tax law, there are special mechanisms that allow a bona fide taxpayer to protect himself from illegal requirements of tax authorities. For example, to exercise the right to obtain information necessary to fulfill tax obligations, the Ministry of Economy, Money and Industry of France has organized 11 information service centers for taxpayers. These centers provide services to inform taxpayers and provide them with necessary instructions on tax and financial services. Similar taxpayer service centers operate in Ukraine as well.

In addition, in France, there is a procedure called fiscal rescript, which gives any taxpayer the opportunity to ask the administration about the legality of a certain economic operation that he intends to carry out in the future. That is, any taxpayer can obtain written advice from the tax administration before entering into a contract or agreement, providing it with all the necessary documents. The administration must respond by stating whether it believes the transaction was an abuse of rights. The deadline for the administration's response is six months. If the taxpayer is not provided with a response within this period, the taxpayer has grounds to believe that the agreement in question is legitimate. If the administration has not raised any objection or if it has not responded in time, it is deprived of the opportunity to qualify the transaction in question as an abuse of right. It is clear that such a period of consideration of the said request in the Ukrainian reality is too long, which will slow down all business processes of taxpayers, but the period of a week is quite acceptable for Ukrainian taxpayers, because business processes in Ukraine are too dynamic.

In the United States there is a procedure of a similar nature (ruling), which manifests itself in two aspects: 1) the interpretation of tax regulations published by the administration (revenue ruling) and similar administrative instructions; 2) the administration's written response to a taxpayer (private ruling) who had previously requested an agreement that he intended to enter into with his counterparty. The recommendations contained in the administration's written responses actually apply to all similar circumstances of taxpayers.
In Ukraine, according to Paragraph 52.1 of Art. 52 of the Tax Code of Ukraine at the request of taxpayers in paper or electronic form, the regulatory authority specified in Subparagraph 41.1.1 of Paragraph 41.1 of Article 41 of this Code, provides them with free individual tax advice on the practical application of certain provisions of tax and other legislation, monitoring compliance with such a regulatory authority within 25 calendar days following the day of receipt of such treatment by the regulatory authority (Tax Code of Ukraine from December 2, 2010 № 2755-VI).

In Germany, the rescript procedure is limited to advising taxpayers on payroll taxes, customs duties, or assessing actual situations in connection with the implementation of fiscal controls.

In Sweden, a fiscal rescript is the issuance by the Tax Law Commission of a preliminary opinion on the tax consequences of an agreement, which may be requested by both the taxpayer and the tax administration. The preliminary opinion is binding on the tax authorities and applies to taxation provided that the taxpayer concerned so wishes.

Thus, explanatory and informational work can be the basis for the implementation of such an approach in Ukraine. The preliminary findings of the tax authorities will allow taxpayers to simplify the assessment of tax losses when planning business activities.

\section{Obtaining the conclusions of the tax authorities}

The following procedure for obtaining an opinion from the tax authorities can be suggested.

The taxpayer submits an inquiry about the tax consequences of the planned transactions and dealings. The tax authority then prepares and gives a conclusion within two weeks. Subsequently, such a conclusion cannot be revised by the tax authority on its own initiative and will be valid for several years. At the same time, it is necessary to establish mandatory payment of state duty for consideration of such requests, as well as to provide protection from official abuse of tax officials. At the same time, the provision of such findings should be made at a level no lower than the main departments of the State Tax Service of Ukraine in the regions and the city of Kyiv, which can be a guarantee against abuse by the tax authorities. At the same time, the tax authority must be given the opportunity to revise its conclusion in certain cases. For example, if collusion has been proven in court or if tax officials have been misled about the actual circumstances. These proposals are aimed at achieving a reasonable balance between the interests of taxpayers and tax authorities.

According to the Paragraph 52.6 of Article 52 of the Tax Code of Ukraine, the central executive authority, which ensures the formation and implementation of 
state financial policy, conducts a periodic summary of individual tax advice, as well as analyzes the circumstances indicating the ambiguity of certain norms of tax and other legislation, control over compliance with which is assigned to regulatory authorities, by providing summarizing tax advice, approved by order of this body (Tax Code of Ukraine from December 2, 2010 № 2755-VI).

Summarizing tax consultations shall be subject to publication on the official website of the central executive body, which ensures the formation and implementation of state financial policy, within five calendar days from the date of their submission.

According to Paragraph 2 of the Procedure for providing generalized tax advice, approved by Order of the Ministry of Finance of Ukraine dated September 27, 2017 № 811, generalized tax advice is provided:

- based on the results of periodic summarization of individual tax advice provided by regulatory authorities to taxpayers;

- in the presence of circumstances indicating the ambiguity of certain norms of tax and other legislation, the control of compliance with which is entrusted to the supervisory authorities.

If the court cancels the order of the Ministry of Finance approving the summary tax advice, a new tax advice is provided, taking into account the findings of the court.

However, under current tax law, the Ministry of Finance of Ukraine does not provide for amendments to the generalized tax advice, which makes it impossible to further deviate from the previous legal position set out in this generalized tax advice and explain the relevant legal provisions in a different way. Thus, according to paragraph 2 of the Procedure for providing generalized tax advice, approved by Order of the Ministry of Finance of Ukraine dated September 27, 2017 № 811, the taxpayer (tax agent and/or its official), who acted in accordance with the generalized tax advice, cannot be held liable, including financial (penalties and/or fines) for actions that contain signs of a tax offense, in particular on the grounds that later such tax advice was changed or canceled. Consequently, only in this paragraph of the said Procedure is the question of changing the generalized tax advice. But the current legislation of Ukraine does not provide for a direct rule on the possibility of making changes to such advice.

Thus, a bona fide taxpayer, acting in accordance with generalized tax advice, is not immune from changes in law enforcement practice, the actual circumstances in which it operates and changes in the tax consequences of certain transactions in economic activity.

At the same time, very often in practice the taxpayer, having individual tax advice received from the tax authorities, in case of their contradiction, does not know which individual tax advice should be followed.

In accordance with subparagraph 112.8 .2 of paragraph 112.8 of Article 112 of the Tax Code of Ukraine circumstances that exempt from financial responsibility for tax offenses and violations of other legislation, control over compliance with which is the responsibility of regulatory authorities, is the commission of the act (action or inaction) by a person acting in accordance with individual tax advice provided to such a taxpayer in paper or electronic form, provided that such advice is registered in the unified registry of individual tax advice or to the summary tax advice and/or to the opinion of the Joint Chamber, Grand Chamber of the Supreme Court on the application of the law, from which it was subsequently derogated (Tax Code of Ukraine from December 2, 2010 № 2755-VI). Consequently, if the taxpayer, having committed a tax offense as a result of individual tax advice, cannot be held financially liable for the tax offense committed.

For these reasons, the Tax Code of Ukraine should also provide for the rule of priority of one individual tax advice over another.

\section{Conclusions}

Currently, one of the main tasks to reduce the number of tax disputes should be the development of conceptual frameworks for reforming tax relations in order to achieve the maximum balance of interests of the parties involved in the process of taxation. This, in turn, is the main prerequisite for effective and fair functioning of the fiscal system of the state.

Finding a reasonable balance between the rights of taxpayers and the powers of the tax authorities means the need to limit the coercive measures applied to the taxpayer to the extent necessary to ensure that the state performs its functions.

The state, in turn, should develop a set of special measures to adapt taxpayers and tax officials to the new tax legislation, regarding an appropriate change in their mentality, improvement of business cooperation and mutual understanding between them, increasing their responsibility for the performance of their tax obligations to the state and the implementation of the rights provided by law.

The basis for achieving a balance between the interests of taxpayers and tax authorities can serve as an appropriate explanatory and informational work.

The following procedure for obtaining conclusions from the tax authorities is proposed: the taxpayer submits an inquiry about the tax consequences of planned agreements and transactions. Then the tax authority within two weeks prepares and gives an opinion. Subsequently, such a conclusion cannot be revised by the tax authority on its own initiative 
and will be valid for several years. At the same time, it is necessary to establish the mandatory payment of state duty for the consideration of such requests, as well as to provide protection against abuse of office by officials of the tax authorities. At the same time, the provision of such findings should be carried out at a level not lower than the main departments of the State Tax Service of Ukraine in the regions and the city of Kyiv, which can be a guarantee against abuse by the tax authorities. At the same time, the tax authority must be given the opportunity to revise its conclusion in certain cases.

Active use by the taxpayer of his rights to obtain conclusions from the tax authorities, for example, in connection with the taxation of income from future agreements on the riskiness of a transaction with a counterparty, which could lead to the blocking of tax bills, will solve the problem before the appearance, thus eliminating the need to resolve a dispute with the tax authority in the future.

\section{References:}

Balakina, A. P. (2005). Chastnyie i publichnyie subektyi v nalogovom prave: voprosyi vzaimodeystviya [Private and Public Entities in Tax Law: Issues of Interaction] / / Problems of Financial Law in Market Conditions in the XXI Century: Proceedings of the International Scientific and Practical Conference / O.N. Horbunova, ed. Moskow: TC Wellby. (in Russian)

Herasymenko, S. A. (1994). Zaschita prav nalogoplatelschikov v arbitrazhnom sude [Protection of the rights of taxpayers in arbitration court]. Moskow. (in Russian)

Panova, I. V. (2000). Administrativnoe proizvodstvo nuzhdaetsya v skoreyshey yuridizatsii [Administrative proceedings need to be juridized as soon as possible]. Journal of Russian Law, vol. 2, pp. 72-76. (in Russian)

Tax Code of Ukraine from December 2, 2010 № 2755-VI. Available at: https://zakon.rada.gov.ua/laws/show/ 2755-17\#Text

Decisions of the Constitutional Court of Ukraine of June 12, 2012 No. 13-rp/2012 on the case of the constitutional representation of 53 people's deputies of Ukraine on the Constitution of Ukraine (constitutionality) of certain provisions of the Tax Code of Ukraine. Available at: https://zakon.rada.gov.ua/laws/show/v013p710-12\#Text 